\title{
9 Social engineering and scientific management
}

\author{
Some reflections on the apartheid \\ public service and historical process
}

Neil Roos

\section{The apartheid public service: some historiographic frames}

There is a burgeoning literature on apartheid South Africa. Much of it focuses on black experiences, the struggle and the uneasy and ambiguous transitions to post-apartheid society. The Truth and Reconciliation Commission (19952002) spawned a genre of confessional accounts. And more recently, a range of memoirs written by former white male conscripts into the South African Defence Force, apartheid's army, have begun to appear on the bookshelves of the upscale Exclusive Books. By and large, the history of ordinary whites under apartheid is left homogenous and monolithic in all of these traditions, and it is premised often on the incorrect dichotomy between conservative Afrikaansspeakers and more liberal English speakers. ${ }^{1}$ The historiographic failure to tackle issues of white class and race formation, identity and everyday life leaves unasked other political and ethical questions clustered around complicity, participation (including knowledge and denial by perpetrators), coercion, agency and its limits.

The National Party's 1948 election victory came as something of a surprise, even to many of the Party faithful. Almost as soon as it assumed office in 1948, the new government had to contend with rising tides of resistance to racial segregation. Deploying all branches of the state ruthlessly, if never entirely systematically, in response to these challenges, the National Party (NP) government did little during its early years to legislate and implement the political geography of separate development for which it would later become infamous. Elements within the NP and those close to it did, however, show their will to surveil certain classes of whites. This imperative applied equally to women as to men and it demonstrates something of the historical distrust and disdain extended by Afrikaner elites to the white poor; the advent of apartheid in 1948 was at best only half a generation removed from poor whiteism and the economic, cultural and psychological ravages of land evictions, unemployment, social dislocation and malnutrition. These interlocking traumas affected not only the white poor but also the middle-class custodians of Afrikaner nationalism, who feared both a dilution of the Afrikaner volk (people) as well as a blurring of the lines between black and white. Working-class (or potentially 
working, or ought-to-be-working) whites were important for the development of apartheid society. At one level whites, especially Afrikaners, needed to fit the volk-ish imagination of Afrikaner nationalism. At another, more practical level, there was a demand for these whites to provide the labour for the expanding apartheid state machinery and also for racially stratified industrial capitalism. And in the late-1940s there did not seem to be much confidence amongst Afrikaner nationalists in government, state departments or universities that whites generally were up to the task. By the early 1960s these issues were more or less resolved and the government underVerwoerd was able to turn to matters closer to his heart, elaborating and applying the broad strokes of separate development and its legitimating ideologies.

This chapter forms part of a broader study into the history of whites under apartheid which investigates historical processes of accommodation in a racial state. In the bigger project I ask firstly how and why white elites, for the purposes of this study, NP politicians, state bureaucrats and Afrikaner nationalist intellectuals, sought to engineer and manage ordinary whites. Far-reaching, elaborate and sometimes invasive instances of reform and regulation took place across a wide topography of institutions and locations and were given effect by the law, by school curricula, by religious homilies and, as we shall see in this chapter, institutional procedures for regulation and discipline. Secondly, I investigate how these subaltern whites, all some distance from the centre of official power and authority, responded not only to the material opportunities and ideological blandishments of apartheid society, but also to the ways that they were regulated and subject to various schema for improvements and sanction. ${ }^{2}$ Part of my objective is to assess how the histories of these processes help us understand the everyday world of whites, at least those in the lower social classes of apartheid society, and some of the diverse ways in which they were bound into and participated in the maintenance of apartheid society as well as the nature and impact of transgression, defiance and indocility.

The bulk of this chapter concentrates on the development of the public service (staatsdiens), with an emphasis on the role of the Public Service Commission (PSC), which was a permanent Commission whose major responsibility lay in recommending public service appointments and promotions, but which evolved under apartheid into a kind of supra-bureaucracy. Most scholarship on the apartheid bureaucracy comes from the fields of management and public administration. ${ }^{3}$ Those from the critical social sciences are few in number, but significant for the ways that they locate the public service in the framework of the apartheid state, as well as contemporary class and race relations. Probably the most well-known is Dan O'Meara's magisterial history of the 'forty lost years' represented by the NP's occupation of office. ${ }^{4} \mathrm{He}$ included a substantial section on the apartheid state machinery, and at the time, his work marked a notable departure from state/capital analyses of apartheid society. He did however confine his interest to the upper echelons of the civil service, and the power of senior bureaucrats to "run" their ministers and shape the policy-making process. ${ }^{5}$ In another departure from the then-dominant Marxist historiography of 
South Africa, sociologist Ivan Evans used a case study the Department of Native Affairs to situate that bureaucracy at the very centre of the development of apartheid between 1945 and $1960 .{ }^{6}$ And in an essay that bore the imprint of the Wits History Workshop, Deborah Posel sought signs of class-based consciousness and organisation amongst white public servants. Despite dissatisfaction with their conditions of service, she argues, public servants were not able to "resist" due to the weakness of their representative body, the Public Service Association, and its unwillingness to challenge the government. Consequently, these officials were unable to enjoy fully the 'wages of whiteness', since they were stigmatised within broader white society as incompetent and the beneficiaries of party political favouritism. Like Posel, I concentrate on the experience of white public servants, linking these to the operation of race in apartheid society more broadly. ${ }^{7}$ By the late 1950s, the public service employed around 30 per cent of all working whites, making it the largest single employer of whites in the country; and between 1946 and 1969, the number of Afrikaner civil servants increased by a staggering 98.5 per cent. ${ }^{8}$ Without any doubt, racially reserved access to fairly well-paid work represented the major foundation for accommodation and complicity on the part of white civil servants; in the idiom of sociologist Michael Burawoy, these jobs were the methodology by which consent was manufactured, at least between those white beamptes (officials) and the apartheid state. ${ }^{9}$ But by itself, the idea of co-optation and "manufactured consent" is too simplistic a rendering of the sociologies of work- race- and state-making that took place in the staatsdiens. I shall argue that attention to the ideologies, regulations and forms of discipline and convention to which white public servants were subject in the workplace helps us understand with greater nuance some of the terms of their incorporation into both the staatsdiens and apartheid society.

While developments in the public service labour process do shed light on large-scale structural features of accommodation that were inscribed in law, in the transformation of the public service and the regulations which governed it, they do not account for diverse white working-class formulations of race and racial identity. In short, more top-down institutional histories are unable to connect the racism of a society and that of a class, or to acknowledge the working-class agency in race-making. Drawing on material yielded by the official archives as well as from interviews, I shall tease out several of these historically constituted strands that existed within the broader parameters of the state and the NP's unfolding apartheid project.

These fragments, including both racial violence and flickers of humanity shared across the colour line, are significant historically and historiographically. ${ }^{10}$ They reveal how subaltern iterations of race did not always coincide with the kind represented by the apartheid state, and thus challenge the usefulness of generic assumption of "whiteness", even when these are refined to, say, "apartheid whiteness". This observation is by no means intended as any kind of apologia. To the contrary it reminds us that race was made not only from the top, but also from the bottom, and it invites us to theorize and speculate how state and subaltern racism were connected. 


\section{The NP and the public service}

Apartheid-era Afrikaner nationalism cohered around the notion of volksgebondenheid (unity of the people) and the aim of uplifting and securing the future of the volk. In the romantic logic of volksgebondenheid, the major purpose of the state was to serve the volk. ${ }^{11}$ O'Meara goes on the claim that in light of the principles of volksgebondenheid, the Westminster-derived culture of civil service neutrality, and the 'mythology of the state-as-arbiter' had little appeal in the NP.The Party hierarchy understood the state, including the civil service, as an instrument to serve the volk, itself embodied in the volksfront of the NP. ${ }^{12}$

Despite the NP's preference for large government and an interventionist state, a sensitivity nurtured by the resilience and complex legacies of white poverty, the public service establishment initially expanded slowly. In 1948 the number of whites employed in the public service (excluding the military and the police) grew by 6,652 to 105,051 , compared to a growth of 9,566 in $1947 .{ }^{13}$ And initially at least, the advent of a new administration in the Union Buildings was not matched by wholesale changes to the upper ranks of the bureaucracy: during the NP's first year in office, only three new heads of department were appointed. ${ }^{14}$ Nor was there much sign yet of the new ethos for the public service described by O'Meara. The sidelining of Major-General Evered Poole, next in line to become chief of the general staff and the resignation of W. Marshall Clark as general manager of the South African Railways in 1949 generated a myth amongst non-Nationalist whites, especially English-speakers, that the NP purged its political opponents from the public service, but there is little evidence of a systematic eviction of non-Nationalists from the senior ranks of the public service. ${ }^{15}$

Beyond the installation of a new government in 1948, the key to understanding the apartheid-era modernisation and expansion of the civil service is the role of the five-man Public Service Commission (PSC), an institution that predated the NP government. In the immediate aftermath of the political transition in 1948, there emerged some tension between the executive and the PSC on the role of the bureaucracy. While the former envisaged a public service that would support its political ambitions and its hope to entrench Afrikaner nationalism as the dominant ethos for (white) public life in South Africa, the PSC commissioners, all veterans of the service and schooled in the tradition of public service "neutrality", favoured one that was less susceptible to executive influence.

An important battle in the turf war between the executive and the PSC took place in 1950, when the post of secretary to the PSC, described by the PSC as 'one of the most important key positions in the Public Service' became vacant. ${ }^{16}$ The minister of the interior recommended one D.J.C. Steyn, employed then in the Department of Justice, but the Commission, ever wary of executive intervention, rejected his nomination. The new secretary of the PSC, it insisted, needed to command the kind of knowledge and experience that could only be acquired through years of close contact with all departments 
and administrations', implying presumably that Steyn lacked such gravitas. ${ }^{17}$ Eventually, the minister appealed successfully to the governor general. ${ }^{18}$ While it is difficult to demonstrate convincingly that Steyn's "political" appointment brought the PSC manifestly closer to the executive of government, it did chip away at the Westminster-style tenet that hitherto governed the relationship between the executive and its administration. Steyn's appointment arguably helped to position the PSC as an institution with the political will to surveil the new class of white beamptes who were central to the development of the apartheid state but not entirely trusted by its political and bureaucratic masters.

\section{Afrikanerisation and the re-making of the white working class in the public service}

Recruiting for the staatsdiens as a whole fell to the PSC, and was a major priority. Histories of recruitment during the early apartheid years expose some of the ongoing tensions generated between ideological and political pressures from the government, and the PSC's more bureaucratic obligations to manage staff and stretch staffing budgets by accelerating the drive for "efficiency". They also yield some insight into the gradual Afrikanerisation of the service.

Employment for whites in the civil service was characterised by a distinction between policy-making (populated increasingly by members of the Afrikaner Broederbond, a secret society of influential white Afrikaner men) and policyimplementation jobs. The latter were associated with procedural, routine and red-tape tasks. This structure, which was imperial in origin and had been refined in the Indian Civil Service during the early twentieth century, permitted a high degree of centralisation. ${ }^{19}$ In the staatsdiens it was manifest in four basic divisions of work: administrative, or managerial; specialist or technical; clerical (whose staff performed skilled white-collar work with few decision-making responsibilities); and a large general division where workers were assigned to a range of low-level manual, administrative, technical and sometimes supervisory tasks. ${ }^{20}$

Anticipating that the heaviest labour demands would be in the general bands, the PSC initiated "special measures" to solicit applications for these posts in 1948, sending circulars and brochures to all magistrates and school principals. While the PSC persistently distanced itself from cruder forms of interventions, the focus of recruiting drives for general staff did shift to the platteland, which was the heartland of the NP's support. The PSC report for 1948 did find it worth reporting that, of 2,004 applications for entry positions, 73 per cent were from smaller centres and country districts. ${ }^{21}$

Overall however the results were disappointing, especially with respect to male applicants. ${ }^{22}$ In its attempts to increase the pool of recruits into the general bands, the PSC was forced to tamper with age limits for entry into the service. Under the 1923 Public Service Act, male candidates appointed to the general division had to be between the ages of 16 and 25, while females between 18 and 25 were considered; the PSC and the minister of the Interior agreed to 
a suspension of the regulations to allow temporary eligibility to the general division of any white man under 50 years of age. ${ }^{23}$ These regulations were not altered for women, testament to the gendered ways that both the PSC and the minister imagined the civil service.

During the first years of NP administration the PSC also tried to recruit staff into the more prestigious clerical bands. Reflecting numerous European and colonial legacies, the most common route to entry into the clerical grades of the civil service was via the Public Service Competitive Examination. ${ }^{24}$ In $1949,1,864$ men and women passed the exam, but to the consternation of the Commission, 1,495 candidates failed to respond to letters informing them of their appointment. ${ }^{25}$ Responding in much the same way as the Indian Civil Service did when it was faced with a shortage of prospective candidates for the upper divisions of the service, the PSC decided in 1950 to do away altogether with the exam. ${ }^{26}$ Instead, it would concentrate on recruiting a bigger pool of white school leavers for entry into the general division, and from this group, identifying candidates for future promotion into the clerical bands. It contacted 5,000, emphasising the gross salary they would earn on appointment. ${ }^{27}$ This, too, was met little success. More saliently, the PSC's vacillation about where precisely to target its recruiting efforts might also have reflected the change in the public service from one dependent upon a relatively large layer of self-consciously professional civil servants to a larger entity structured, as I will argue, on centralised authority, hierarchical order and ultimately the work of large numbers of relatively junior staff.

Under apartheid the PSC incorporated women into the staatsdiens more comprehensively than before. Thus in early 1950 the PSC overrode the advice of the Public Service Commission of Enquiry and ruled that women could progress to senior clerical or administrative posts, in other words, enter the management bands. ${ }^{28}$ The proviso, which kept patriarchy in the public service intact, was that 'staff controlled by the [female] incumbent should be predominantly women'. ${ }^{29}$

It is however noteworthy that just as the PSC expanded the permanent employment of women and made provision for their training and advancement, it envisaged that this would occur largely within particularly junior ranks of the service. ${ }^{30}$ Revealing the myth amongst the PSC that women represented short-term and expedient help in the staatsdiens, the number of women on the permanent roster remained consistently lower than those deemed "temporary". Nevertheless, the trend towards the permanent employment of women was a cause of concern to the PSC, as by 1958 it insisted that Departments not only report on the number of women on their respective establishments, but also motivate and explain any increases. ${ }^{31}$

Complaints about the paucity and quality of white applicants was a recurring theme in the PSC's annual reports for much of the decade as it noted repeatedly that the number of applications for employment fell far short of requirements. ${ }^{32}$ In its own analysis, the PSC attributed the critical shortfall of applicants to 'competition for the services of a work seeker'. ${ }^{33}$ The conditions 
of competition noticed by the PSC were rooted in a rapid growth of the national economy after the Second World War. After the war, new goldfields were opened up in the Orange Free State, as well as to the east and west of the original Witwatersrand goldfields. Wartime import substitution had provided a spur to manufacturing, and there was substantial expansion in the metals, engineering, textiles and chemical industries. Net National Income was on an upwards trend. ${ }^{34}$ In an economy with a segregated labour force, this growth spread thin the available pool of white recruits.

In a tight labour market for whites, the public service was poorly positioned to attract as new recruits those able to access more lucrative private sector employment. The class and social stratification of South African society and respective histories of proletarianisation amongst Afrikaans- and Englishspeaking whites meant while English-speakers were generally better-positioned to enter the private sector, the bulk of the new white public servants were Afrikaners. These structural and cultural factors, more than the operation of Tammany Hall-type interventions, contributed to the Afrikanerisation of the civil service. The particular ethnographies of recruitment into the public service, overseen by the PSC, confirm Posel's observation that public servants under apartheid developed into a disrespected stratum of white society. And more important for the purposes of this chapter, expansion during the first decade of apartheid brought into the fold of the public service a large number of people, already exposed at the town hall and the pulpit to certain ideologies about progress, the volk, godsdienstigheid (religious observance) and the races. As discussed later, the structured world of the staatsdiens added layers of regulation and methods of discipline to these ideologies, and sometimes modified them.

In the late 1940s and early 1950s the PSC's recruiting measures were based on posters spelling out the salaries and terms of employment in the civil service, as ineffectual as they were unimaginative. The PSC blamed the failure of successive recruiting campaigns on 'a great deal of ignorance about the Pubic Service at universities and schools as well as among members of the general public', yet it persisted with this approach until 1953, ${ }^{35}$ after which it engaged the services of an advertising agency to produce publicity material. ${ }^{36}$ This material is useful in the ways that it offers a tableau of how the PSC imagined the world of work in the civil service.

In 1955 for instance it published a brochure titled Successful Careers in Service of Your Country. ${ }^{37}$ This began by enunciating the civic and personal dimensions of work in the service. It was a golden age to serve South Africa, and the civil service represented a golden opportunity to serve the country and its people. The service presented young people with the prospect of personal development, and 'gaining insight into all realms of die volkslewe' - the life of the volk. In an appeal that was rather off the mark given the ways the public servants were in fact seen by the white public, it declared that the public service was well-suited to those who cared for their community and were 'willing to accept the status of leadership within the community'. ${ }^{38}$ Hard work could bring quick advancement and would constitute 'service of the nation, work that could not 
possibly be uninteresting' - an observation that demonstrated the author's proximity, ideologically and discursively, to Afrikaner nationalism. Touching on the ideal of stability central to emerging middle-class whiteness, it pointed out to potential candidates that their position and future were protected by law, that they could expect regular salary increments and also assistance with insurance and the purchase of a house. This brochure was distributed to all high schools, and elicited an 'encouraging' number of applications. ${ }^{39}$

The expansion of the public service effectively ended poor whiteism and erased at least the material traces of the Great Depression from white society: in a sense, the state was the creator of a large clerical white working class. But this growth stimulated other contradictions in white society at times of growth and of war: a shortage of white labour. The PSC was thus obliged to rely substantially on "temporary units", usually pensioners or married women. In 1958 for instance, the public service engaged 2,109 men along with 2,567 temporary male employees; 942 women were taken on, as against 916 temporary appointments. ${ }^{40}$ Ironically, just as the PSC's recruiting practices and promotions policies sought to consolidate Afrikaner nationalism's gendered hierarchies, the growth of the public service to meet the needs of the apartheid state obliged it to rely increasingly on the labour of white women.

\section{Scientific management and a "Non-Political" public service}

In addition to recruiting, the PSC's most significant work during the first decade of apartheid was to reform the organisational sociology of the public service. These changes brought centralisation, which positioned the public service well as the bureaucratic counterpart to ideologies of Afrikaner nationalism and corporativism. In the early twentieth century American engineer Frederick Taylor's principles of scientific management, with their siren song of efficiency, were implemented in much of the industrial world, including South Africa. ${ }^{41}$ By the 1940s the novelty of scientific management had worn off, but it received a boost following the success of the quality control movement, pioneered in Japanese industry by W. Edwards Deering. South African industrialists like Albert Wessels, founder of the local affiliate of the Toyota Motor Corporation, were immensely impressed by the possibilities of quality control, and no doubt discussed its merits amongst their peers back home. ${ }^{42}$ It was however something of an innovation for the management of bureaucracies that the PSC applied some of the principles of quality control to the reorganisation of the staatsdiens.

Scientific management was introduced to the public service piecemeal, and in rather unconventional ways, beginning not with the usual organogram and description of posts, but with the introduction of new techniques for reporting on individual staff performance and systems for merit assessment. And it targeted white public servants. This approach might have reflected not only the current popularity of quality control but also contrary demands on the PSC:just as its commissioners and technocrats were developing strategies to implement 
scientific management, they were also expected by government to absorb into the public service workforce large numbers of fairly unskilled whites. Working to an organogram, analysing the posts and measuring the work outputs ascribed to it, would surely have exposed these contradictions, whereas the implementation of individual merit assessment and "quality control" allowed officers to be evaluated and some sort of rank order for advancement be established; as the PSC later explained, to 'eliminate the whispering campaigns so prevalent in the Service today', presumably the belief that those close to the NP received preferential treatment. ${ }^{43}$

For much of the twentieth century white South African elites asserted the European genealogies and connections of white South African society, part of an ongoing project to invoke Europe's intellectual legacy and so lay claim to European versions of modernity. ${ }^{44}$ Thus as the PSC announced a new 'standard staff report form' it was proud to report that this was developed after intensive investigations of promotions practice in Europe and North America. ${ }^{45}$ The aim of the new reporting form was to arrive at a "score" of each public servant's performance. Yet just as the new system sought to silence "whispering campaigns", it created a bureaucratic framework for surveillance, for discipline and other versions of favouritism. For behind the illusion of fairness and objectivity it asked probing and intimate questions about the use of intoxicants and narcotics, dress, personal demeanour, personality, physical appearance and "special" qualities. ${ }^{46}$ In addition to these substantial written reports, each staff member had to be interviewed to 'place before the Committee such facts as may have a bearing on their merit assessment'. ${ }^{47}$ In December 1952 it emerged however that the Department of Inland Revenue refused to implement the new system. Noting that Department's refusal to carry out a 'full scale personal inspection' the secretary of the PSC prepared a report insisting that it carry out 'full scale merit assessment' and warning that further defiance would warrant Cabinet censure with serious consequences for the senior officers of the Department. ${ }^{48}$ Merit assessment sought primarily to standardise procedures for management of individuals in the public service. But it went beyond measuring individuals' work, as it also created an objective criterion to monitor and regulate those departments who resisted the tendencies towards centralised control implicit in merit assessment and scientific management. And quite plausibly, it provided a screen behind which other networks of influence, activated by the Broederbond, operated to advance the careers of favoured mid- and senior-level bureaucrats.

In August 1954 a conference of all heads of department, to discuss merit assessment, was held under the chairmanship of Donges, the minister of the interior who had Cabinet oversight for the PSC. ${ }^{49}$ Although the subject was merit assessment, this gathering represented a significant event in the public service's history of centralisation: heads of department had not previously been successfully summoned together, and the PSC's capacity to convene the meeting also signalled its evolving role as a supra-bureaucracy. By that year, "good progress" had been made in extending and implementing properly merit 
assessment, and in its report to the heads of department, the PSC pointed out that the "difficult periods" in the introduction of the system, which it hinted darkly were inspired by party political allegiance to the old United Party government, had ended. ${ }^{50}$

In 1957 it reported that 8,561 officers were assessed, and that the system had been extended to those who did not normally qualify for merit assessment. ${ }^{51}$ Numbers continued to grow: 9,059 in 1958, 8,904 in 1959 and 10,549 in $1960 .{ }^{52}$ The PSC attributed the steady increase in the number of officials who were assessed to the shortening of the qualifying period of service, and this in turn might have represented a drive by the PSC to promote the upwards social mobility of public servants, which coincided with the broader Afrikaner nationalist imperative to advance the interests of the volk. The merit system did however contain at least one contradiction. As we shall see, the staatsdiens was expected to provide employment for whites who would otherwise struggle to find work in the "open" market, even one circumscribed by a colour bar. They, along with other whites in the lower bands, and of course women retained in "temporary" positions were unlikely or unable to qualify for promotion. This lessened the impact of merit assessment as a tool to regulate these officials.

Merit was the first dimension of the PSC's reform of the operation and management of the public service around principles of scientific management, and it gave early momentum to discourses within the service about efficiency. As the PSC later observed, merit allowed it to identify and then discipline, demote or in some cases, dismiss those who performed poorly. ${ }^{53}$ In its early days, heads of department were reluctant to connect the new assessment system to sanctioning officers for inefficiency and the PSC noted that instead of leaving this task to the discretion of departments, it would have to develop the means to prosecute inefficiency under the 1923 Public Service Act. The existing Act, legislated long before the drive to efficiency, was however cumbersome, and by 1953 the PSC had managed to secure an amendment. In that year, it reported that one female officer had been reduced in rank and her salary reduced by £20 per year, while a male officer was dismissed. ${ }^{54}$ It boasted later that those subject to merit assessment showed a marked improvement in the quality of their work, although there may have been an element of self-justification in this claim, given the energy and resources allocated to developing its procedures and application. ${ }^{55}$

Although it was seldom enunciated explicitly, public servants were expected to know a cultural curriculum primarily made up of knowledge about race but also gender, and sometimes, class. As the racial and gendered struts of apartheid society were bulked up, the racial and gendered knowledge required of its servants receded to the background of the archive, evidence of the taken-forgranted presence of these hierarchies in white South African society. At times, however, the official archive does reveal quite clearly the demand for such knowledge. 'What is your knowledge of coloureds', asked a 1951 memorandum setting out the questions for merit assessment. ${ }^{56}$ 
The demand for bigger government as apartheid's imprint on South African society became larger and more complex, along with a government decision to suspend increases in the public service establishment, pushed the PSC to engage more deeply with scientific management. Moving from monitoring of the individual, it began to pay increasing attention to 'methods and systems of work' ${ }^{57}$ In other words, greater efficiency.

By 1954 the PSC had deployed management experts at the State Sawmills in Pretoria and with great delight, it reported that this experiment, on a very small scale, had yielded remarkable efficiencies: production increased by 14 per cent, productivity of "European" and "native" staff by 218 per cent and 201 per cent respectively, and a saving of $\mathcal{E} 54,741$ effected that year. ${ }^{58}$ In what became a model for the training of public service werkstudie (work-study, or efficiency) officers, eighteen were trained at the Pretoria Sawmill site in the methods of analysing and improving workplace efficiency. ${ }^{59}$

After its early successes, the PSC proposed that Organisation and Methods Study (O\&M) sections be established in every state department. ${ }^{60}$ During that year already it designated 100 staff members as O\&M officers. ${ }^{61}$ By the following year it had in place a curriculum of training courses. These courses covered the fundamentals of scientific management like techniques of work measurement, analysis and improvement of organisation, calculation of staff requirements and office mechanisation. ${ }^{62}$ The PSC's enthusiasm for scientific management was unwavering, and by 1961 it had trained 169 O\&M officers, and had decided to send several O\&M inspectors to Canada and the USA to study the latest innovations. ${ }^{63}$

Reflecting the growing international interest in human resource management the PSC in the late 1950s added this feature to its repertoire of management instruments. Its particular interest was in 'occupational adjustment problems', and between 1959 and 1961, vocational psychologists investigated 442 public servants. The reporting categories used by the PSC were vague: persons misplaced (158); persons who needed psychological therapy and occupational guidance (179); and persons with other problems (105). ${ }^{64}$ Given however the extent to which merit assessment roamed into the reaches of the personal, the overarching ideological framework of the bureaucracy and the extent to which the PSC sought to standardise work and eliminate dissidence, it is not implausible to presume that in addition to more conventional cases of people being in the wrong jobs, or suffering more universal psychological disorders, there were included in this number officials who were "misplaced" or "problematic" in terms of the cultural strictures of apartheid society. In a novel study, Will Jackson draws on some of Frantz Fanon's key claims to demonstrate how conditions of colonialism created certain psychopathologies amongst whites in colonial Kenya. ${ }^{65}$ Quite possibly, similar dynamics were at play within the occupational adjustment scheme. Moreover, it became another tool for discipline, regulation and the production of sameness amongst civil servants.

The drive for efficiency in the staatsdiens was not without its contradictions, and it often clashed with the apartheid policy of "civilized labour" for whites, 
and the Afrikaner national ideal of providing livelihoods for otherwise unemployable whites. Referring to staff outside the administrative sections, in 1951 Minister of Labour Ben Schoeman announced that

we should not create a permanent stratum of unskilled European labour. We should ... take out those unskilled Europeans who are adaptable, who have the necessary aptitude ... [and] give them training. That is how we will get the movement from the unskilled, right up to the skilled. ${ }^{66}$

Effectively his declaration re-located the colour bar to a higher level, and nowhere were the principles of civilised labour applied with greater vigour than in the staatsdiens. Between 1948 and 1959 for instance, whites working in the railways were steadily re-assigned from labouring to supervisory positions during that decade the number of white "railworkers" (labourers) fell from 17,407 or 17.7 per cent of the total number of white employees to 12,131 or 10.7 per cent. ${ }^{67}$ The tasks which the men performed hardly changed, yet their wages were significantly improved. Native Representative in the House of Assembly Margaret Ballinger tartly noted that "non-Europeans" were being engaged from $2 \mathrm{~s} 6 \mathrm{~d}$ to $3 \mathrm{~s} 6 \mathrm{~d}$ a day, while "Europeans", doing the same work, were paid at supervisors' rates and taken on from $8 \mathrm{~s} 6 \mathrm{~d}$ to $14 \mathrm{~s} 6 \mathrm{~d}$ per day. 'This is going to mean a very considerable increase in the burden of the Public Service', she concluded. ${ }^{68}$

Since at least the advent of Union in 1910, whites had found the state a source of sheltered employment. After the NP took office, however, it tried to expand protected employment to cater specifically for disabled and poorly educated whites, with the Ministry of Health and Welfare its greatest champion. Numerically these whites were not a significant source of electoral support for the NP, but culturally, they struck a chord with Afrikaner elites who held a deep dread of whites being reduced to pecuniary, beggary and the socioeconomic status of South Africa's subject races. Plans to provide sheltered work took two forms. Firstly, the Ministry proposed the idea of establishing factories and workshops to employ physically and mentally handicapped whites, especially the blind and 'the type who won't find work easily', and to this end in August 1949 the minister convened a Commission of Enquiry into Protected Work. The PSC's submission to the Committee revealed differences between it and the government on the role of the state in supporting these whites. Presenting as a case study two state-run factories for the disabled, one at Pietersburg and the other at Potchefstroom, the PSC showed that while the Potchefstroom factory cost the fiscus in 1948/9 $£ 9,546$, the provision of pensions for the entire complement in sheltered work at the factory would cost only $\mathcal{E}^{4,000}$ per year. Faced with these wretched statistics, the Commission recommended that it was neither sensible nor economic to implement a system of workshops and factories for the white disabled, and if the government wished to pursue the idea, it should do so in collaboration with private business. ${ }^{69}$ The PSC won this round, as the minister quietly dropped his proposal. 
Secondly the minister prevailed upon his colleagues in other departments to employ another category of whites that 'wouldn't find work easily'. These men and women were not physically disabled but were described in the brutish language which Afrikanerdom's elite sometimes used towards its subalterns as halfgeskooldes - half-educated people. His directive was interpreted by senior departmental functionaries to also incorporate 'idlers, hoboes and similar types', or as they were described in some official directives as blanke tsotsis, a racially loaded term implying that they were not-quite-white thugs. ${ }^{70}$ Those who were employed were incorporated into the public service, and in the sanitised "bureaucratese" of PSC reports, their jobs were listed as 'non-prescribed posts', in other words, jobs that lacked formal job description. This was an anomaly in an increasingly regulated public service, and in 1949 they numbered 1,122, in $1952,1,748,1955,1,510$ and by $1961,1,361 .{ }^{71}$ These workers were used as bag-carriers in the post office, porters in hospitals and railway stations, and as sub-wardens in work colonies and psychiatric facilities. In the work colonies it was halfgeskooldes who marshalled the grinding routines that constituted "rehabilitation" and they were also responsible for punishing detainees. In short, the halfgeskoolde public servants, although few in number, stood at some of the apartheid state's punitive edges, a site where the state was "made real" for South Africans, both black and white.

Scientific management in the public service is important for our argument. It changed substantially the structure of work in the staatsdiens, and it created a framework for the introduction of new and expansive disciplinary interventions. Effectively these measures provided some of the structural conditions to mark out the fields of agency available to public servants in their workplace. Through its efforts to standardise work procedures, the PSC organised the labour process in ways that were not crassly nor explicitly "political", but which brought to it centralisation and an emphasis on hierarchy that served well the interests of a corporativist-type state. And the PSC's reforms made efficiency the language of the staatsdiens. The archival record gives few examples of reference by public servants to, or commentary on, apartheid's projects, grand or little, but it is replete with anxious references to "efficiency". This suggests that public servants - with the obvious exception of those more senior officials responsible for policy-making - were not compelled to enter the difficult political, ideological and moral terrain of apartheid, but needed instead to make regular and consistent choices about "efficiency". In addition, behind their rational and scientific guise, the standards for merit assessment included criteria associated intimately with the type of knowledge required for governance in a racial state.

If the organisation of the labour process, the mechanisms for monitoring and correction offered by scientific management and seldom-specified cultural imperatives were measures designed to manage the dispositions and everyday world of public servants, so too was induction. In 1956 the PSC reported that it was ready to implement an induction training programme that aimed to 'orientate the young public servant for his career and broaden his public service 
background'.$^{72} \mathrm{~A}$ year later it reported that it had laid on 14 part-time induction courses, each lasting three weeks. It gave details of the courses:

i The constitution, organisation and functions of the State;

ii How the State operates;

iii The place and role of the public servant in the scheme of the State's activities;

iv The public servant and his conditions of service;

$\mathrm{v}$ The public servant and his work;

vi The public servant and the citizens of South Africa. ${ }^{73}$

In addition to its explanation of the detail of public service work, the emphasis that induction training placed on the state, and the public servants' duty to the state and "his" role in connecting citizens (white ones) to the state tied in neatly with the concerns of Afrikaner nationalism. By the following year the PSC could report that clerical assistants on probation, as well as the majority of clerical assistants appointed over the previous two years had undergone induction training. ${ }^{74}$ Clearly younger and more junior entrants were targeted for training. The way that the public service induction training was conceived and implemented as well its timing is significant. It suggests that in the face of rising consumerism, as well as growing instances of youth rebellion, manifest most alarmingly amongst white youth in South African by the increasing visibility of "Ducktails", the PSC management was showing signs of anxiety that young white public servants' steadfastness, their sense of purpose and their commitment to the volk needed reinforcement. Through the rest of the decade, and up to the late 1980s - maybe beyond - this anxiety simmered across elite echelons of white society.

During the early apartheid years, the white staff establishment of the public service became increasingly Afrikanerised. The innovations and structural reform of the staatsdiens initiated by the PSC made it centralised, installed sophisticated management tools to advance, or retard, individuals' progress, and discouraged public servants from seeing beyond the range of their immediate jobs, or in the case of more senior officials, those of their subordinates. The public service during the first decade of NP rule developed as a formidable "steel frame", not only for the administration of apartheid society but also for the management of beamptes. ${ }^{75}$

\section{Beamptes' agency and everyday race-making}

As far as its ambitions went, and in the self-assessment of its senior officials, the apartheid state was sturdy, coherent and rational, with an efficient administrative machinery. A turn to the social history of beamptes lower down the public service hierarchy does however indicate tremors and limits in the state's capacity to manage whites. For instance, these excursions reveal beamptes iteratively developing their own understanding not only of racial hierarchies but of social 
ones within the body politic of white society. They show officials acting "compassionately" in a system otherwise premised on the impersonal and immutable banalities of bureaucratic regulations rather than any measure of empathy or humane-ness. They demonstrate unexpected instances of history across the colour line. And they expose an underbelly of popular racist violence that even the apartheid state, itself built on many layers of violence, would repudiate.

Thus, we are witness to an escalating disagreement between two bureaucrats, both white men, which had one of the antagonists issuing something of a monologue on race relations, social class, and the kind of etiquette necessary to mediate interactions between people of different race and social origins. It started with a water dispute between the state entomologist and the medical superintendent of Tower Hospital in Fort Beaufort and boiled over into an angry complaint of how a Mr Yorke, head male nurse at the hospital, addressed the entomologist. In the hospital dining room Yorke 'hectored and brow-beat' the entomologist, in front of junior staff. This 'high-handed action and attitude' to a superior was unacceptable, wrote the entomologist; moreover, Yorke's demeanour and tone were more suitable for 'addressing a non-European labourer'. The entomologist's outrage seemed most piqued at Yorke's disregard for the multiple hierarchies of apartheid society (although he was silent on gender), and it suggests that he had a clear vision of the social order that was beginning to coalesce under apartheid. His understanding was cast in a grain markedly finer than the broad racial categories that had currency amongst apartheid elites in the early 1950s.

Then, the strange case of the "Mauritians". This is a case of greater historiographic significance than political, for it challenges the idea of a state as all-powerful, and it also offers an instance where officials were able to resist and overturn not just the letter of the law but its very intent. One of the foundations of apartheid legislation was the 1950 Population Registration Act which obliged each inhabitant of South Africa to register according to racial characteristics as white, African, coloured or Asian. For state officials the logics of bureaucratic work meant that they could not tamper with these racial categories. There is however evidence that at least some of them acted with what amounted to compassion. In Durban they did so by making use of the sub-category "Mauritian". "Mauritian" was a designation devoid of any particular or unique racial characteristics: no one knew what a "Mauritian" should look like, at least according to the grammar of apartheid bureaucracy, except that "Mauritians" were a sub-category of the white racial group, and there were examples where officials subverted the Act by reclassifying families, usually coloureds or Asians, as "Mauritian". This measure enabled them to become white and so claim access to better wages, education, health care and subsidised housing. Examples like this are few and far between, and they hardly tell against the relentless inhumanity of apartheid. But they do offer a counter against the totalising assumption of the staatsdiens as a wholly effective cypher for apartheid ideologies, an institution that completely stripped from its officials any possibility of agency, defiance or human solidarity. 
Apartheid society was premised not only on white privilege, but also on violence. It was important for the sort of "order" imagined under apartheid that violence was bureaucratic and regulated, sometimes juridical, and always the prerogative of the state. Lynch-type violence, exercised by individuals, was not tolerated. In 1957 one G.O. Opperman, a clerk in the Department of Labour was riding his bicycle inside the corridor of an office, 'when his progress was impeded by [a] native who was walking through the doorway at the time'. It appears that this annoyed Opperman, who 'there-upon assaulted the native'. The archive yielded no pronouncements or regulations on violence although it does show swift punishment for those white public servants who presumed for themselves. Opperman found himself discharged from the public service and charged by the police. ${ }^{76}$ Of the assaulted African, nothing, after his brief and painful vignette as the object of Opperman's unacceptable assault. That this episode attracted such detailed correspondence suggests that violence of the sort demonstrated by Opperman was probably quite uncommon, a tremor that unsettled the style of race and social relations, the form of white supremacy, that underlay apartheid.

\section{Work in the public service and belonging in the apartheid state}

The history of the staatsdiens during the formative years of apartheid supports arguments made by Posel that apartheid state-making was not 'an essentially cumulative process' that developed according to some grand ideological blueprint, but was rather the product of struggles within and beyond the state. ${ }^{77}$ Much the same argument applies for race-making and the idea of what it meant to be white. Given the long history of elite Afrikaner anxiety about the cultural and political reliability of working-class and poor whites, it is hardly surprising that the new government invested so much attention surveilling, policing and where necessary reforming whites in the lower strata of society, including those who occupied "policy implementation" posts in the staatsdiens. As we have seen, these intentions were the subject of contestation from lowerlevel beamptes. It is an irony that the very whites who caused Afrikaner politicians, bureaucrats and intellectuals such distress, and were the subjects of official attention, were sometimes relatively unaffected by the battery of public service regulations because possibilities for upwards mobility offered by the merit system were simply beyond them.

While Posel points out that public servants were not able to enjoy in full the "wages of whiteness", racially privileged work, and a public service that expanded its corps of white employees was the most important means by which the consent of white public servants for the apartheid state was reaffirmed. This consent however was for a general principle of racial supremacy and job reservation for white workers, notably those in the public service, and it left open questions about the particular form of the state or the specifics of white citizenship. This imprecision represented the realpolitik of building an 
electoral base, but it also enabled the articulation of a variety of ideas about what it meant to be white: these differences gave the grounds for many of the instances of "defiance" by whites.

The public service underwent major reform during the early years of NP rule, and in trying to elucidate the terms of this accommodation, I have concentrated on how these reforms contributed to managing the beamptes. I have also argued that to understand the ethnography of work in the public service, we must appreciate the role of the PSC in managing its expansion and reorganisation, and how, incrementally, the apartheid-era staatsdiens broke with earlier traditions of the service.

Although the PSC resisted clumsy political interference in appointments, it did oversee recruiting practices that shifted the public service closer to the demographic and ideological heartland of Afrikaner nationalism. The progressive introduction of scientific management standardised work across departments and reduced the possibility of departments or individuals acting in renegade ways. It provided systems to monitor public servants and measure them on aspects of their work that related to both the technical requirements of the job as well as the new elite's frames of ideological and cultural reference. These matrices furthermore provided the basis for advancement, for the identification of those with 'occupational adjustment problems' and also for punitive action. Collectively, the role of the public service labour process in managing whites suggests that just as the development of the apartheid state was a haphazard and contradictory process, there was in fact evidence of the kernel of a project to re-imagine society in ways beyond the pragmatics of white supremacy. While the full horrors of apartheid state planning and its efforts to manage populations through social engineering would be visited upon blacks from the 1960 s, this kind of state-making vision was manifest earlier in endeavours to manage whites, at least those employed by the state and thus at easy reach.

The expansion of the public service was responsible for the emergence of a new, increasingly Afrikanerised, class of whites employed in clerical jobs. And given the size of the staatsdiens, it was the major institution whereby whites participated in the production of apartheid society, without having to act in specifically racist ways, or demonstrate any explicitly political partisanship. This condition prevailed for much of the apartheid period and arguably, it enabled many whites to assert, after the fact, that they "did not support apartheid". Such claims, however, are built on bad faith as they consciously ignore the privilege and racial supremacy that lay at the heart of apartheid society, and they demonstrate the self-deception and lack of thinking invoked by Hannah Arendt to describe everyday morality in authoritarian societies elsewhere. ${ }^{78}$

As we have seen, white public servants demonstrated significant agency in the ways in which they staked their place in apartheid society, and the kind of identities, behaviour and racial rules they assumed. Even in the workplace, the planes and affective currents of the archive suggests that they were indocile, and as the case studies suggest, they were occasionally defiant. The beamptes' assertion of some autonomy and their transgression is significant - and it isn't. It 
should not for a moment descend to the kind of cynical revisionism that seeks to put a human face on apartheid's beneficiaries or moves these whites into a column headed "opposition", and at every turn these beamptes' history reminds us how they too participated in race-making, that race was made not only from the top, by the state, but also from the bottom. It does however challenge some of the moral and historiographic certainties about apartheid history: about the coherence of the apartheid project, about the stability of racial categories and about the existence of riposte and challenge from within white society, and its limits. And the shards of humanity which they sometimes showed should serve as a pedagogy against essentialised whiteness, a tool in unmaking the history of whites as one exclusively of racial domination, self-interest and deception, accommodation and complicity. Yet the examples represented in these case studies also reminds us that just as these public servants occasionally acted compassionately or crossed the colour line, they did not repudiate apartheid. The Durban officials used the very language and categories of apartheid to help a few families "cross". Testament, perhaps, to the observation that while there were many currents of racial supremacy in apartheid South Africa, and that some of these jarred against each other, few whites were either immune or hostile to racist ideologies.

\section{Notes}

1 I follow Medick, who invokes 'ordinariness' as distinguished from 'high' politics. See Medick, 'Missionaries in the Row Boat?'. I use the term in reference to those described in some historiographic traditions as a working class, whites who broke their way into the 'middle class', and those separated from the mainstream of ordentlike (respectable) white society. It includes both Afrikaans- and English-speaking whites.

2 Following the earlier, more historical tendencies within Subaltern Studies, I use the term 'subaltern' to refer to conditions of domination and subordination within the power structures of a class-divided society.

3 See for instance Grimbeek, 'Vereniging van Staatsamptenare van Suid-Afrika';Visser, 'Die Vereniging van Staatsbeamptes'; Adonis, 'The Public Service Association's Response'.

4 O'Meara, Forty Lost Years.

5 Posel, 'Whiteness and Power in the South African Civil Service', 100. A note on terminology and scope:The staastsdiens incorporated the civil service, referring to individuals in departments directly involved with the daily exercise of administration and governing, while the public service itself was broader and included teachers, scientists, nurses, mechanics, road- and railway-workers, and all those who were employed by the government and rendered a service to the public. Parts of this essay concentrate on those in the administrative divisions and other parts of it take case studies from work in the public service more generally.

6 Evans, Bureaucracy and Race.

7 Posel, 'Whiteness and Power in the South African Civil Service', 99-119.

8 O'Meara, Forty Lost Years, 61-62; Archive for Contemporary Affairs, University of the Free State, Bloemfontein (hereafter ARCA), PV 71: C.D. Taylor collection, 1/11/4/9/1/10/1, Notes on Public Service.

9 Burawoy, Manufacturing Consent.

10 See Painter Southern History Across the Color Line, 2.

11 O’Meara, Forty Lost Years, 41. 
12 Ibid., 61-62.

13 Posel, 'Whiteness and Power in the South African Civil Service', 102; Public Service Commission, Thirty-Seventh Annual Report of the Public Service Commission (Pretoria: Government Printer, 1948), paragraph 69.

14 Public Service Commission, Thirty-Seventh Annual Report of the Public Service Commission, paragraph 46.

15 Giliomee, The Afrikaners, 493. The archival record seems to support Giliomee's assertion.

16 Public Service Commission, Thirty-Ninth Annual Report of the Public Service Commission, paragraph 43.

17 Ibid., paragraph 44.

18 Ibid., paragraphs 44-45.

19 Potter, 'The Last of the Indian Civil Service', 26.

20 With the exception of teachers and nurses, black workers were all confined to the general division where they earned considerably less than whites.

21 Public Service Commission, Thirty-Seventh Annual Report of the Public Service Commission, paragraph 88.

22 Public Service Commission, Thirty-Ninth Annual Report of the Public Service Commission, paragraph 203.

23 Public Service Commission, Thirty-Eighth Annual Report of the Public Service Commission (Pretoria: Government Printer, 1949), paragraph 17.

24 Ibid., paragraph 61.

25 Public Service Commission, Thirty-Ninth Annual Report of the Public Service Commission, paragraphs 190-191.

26 Ewing, 'Administering India', 45.

27 Public Service Commission, Fortieth Annual Report of the Public Service Commission (Pretoria: Government Printer, 1951), paragraphs 137-138.

28 Public Service Commission, Thirty-Ninth Annual Report of the Public Service Commission, paragraphs 143-144.

29 Ibid., paragraph 92. This, incidentally, was a similar condition to one specified in 1961 for 'Bantu Officers', who were expected to take on 'leading roles in the administration of their own communities'. Public Service Commission, Forty-Ninth Annual Report of the Public Service Commission, (Pretoria: Government Printer, 1960), paragraph 23.

30 National Archives of South Africa, Pretoria, (hereafter NA), GG 2148 71/294, vol.1, 'Opleiding van Tiksters', Staatsdienskommissie, 10 Januarie 1956; 71/294B vol. 1, 'Tiksters vir permanente aanstelling', Staatsdienskommissie, 16 Oktober 1956.

31 NASA, PSC 19/22/F/1, GG 2148, vol. 3, 'Statistics required for annual report', 12 December 1958.

32 See for instance Public Service Commission, Forty-Second Annual Report of the Public Service Commission (Pretoria: Government Printer, 1953), paragraph 55. Public Service Commission, Forty-Third Annual Report of the Public Service Commission, paragraph 52.

33 Public Service Commission, Thirty-Ninth Annual Report of the Public Service Commission, paragraphs 297-298.

34 Houghton, 'Economic Development, 1865-1958', 36-48.

35 Public Service Commission, Forty-Fourth Annual Report of the Public Service Commission (Pretoria: Government Printer, 1955), paragraph 26.

36 Ibid., paragraph 63.

37 Ibid., paragraph 64.

38 Posel, 'Whiteness and Power in the South African Civil Service'.

39 Public Service Commission, Forty-Fifth Annual Report of the Public Service Commission (Pretoria: Government Printer, 1956), paragraph 28.

40 Public Service Commission, Forty-Seventh Annual Report of the Public Service Commission (Pretoria: Government Printer, 1958), paragraph 50. 
41 Lewis, Industrialization and Trade Union Organization in South Africa; Webster, Cast in a Racial Mould.

42 Wessels, Farmboy and Industrialist, 154-155.

43 NASA, GG 2148 71/294 vol. 1-1951, Duty Sheets and Procedure Manuals, Forms Z 190 and $\mathrm{Z} 191$.

44 They set out, in a sense, to 'provincialize' and later, to 're-make' Europe. For an elaboration of the cultural arguments and ripostes at play, see Chakrabarty, Provincializing Europe, especially $1-23$.

45 Public Service Commission, Thirty-Ninth Annual Report of the Public Service Commission, paragraph 248.

46 NASA, GG 2148 71/294 vol. 1, Omsendminuut SDK 2/G. Merietebepaling, 13 Januarie 1956. Sekretaris: Staatsdienskommissie.

47 NASA, SDK 2/G/3 vol. 6, L.E.L. Kleuver, Secretary, PSC-The Commissioner for Inland Revenue, 30 December 1952.

48 NASA, SDK 2/g/3 vol.6, Inland Revenue Merit Assessment 1952.

49 Public Service Commission, Forty-Third Annual Report of the Public Service Commission, paragraph 48.

50 Ibid., paragraphs $73-74$.

51 Public Service Commission, Forty-Sixth Annual Report of the Public Service Commission (Pretoria: Government Printer, 1957), paragraph 90.

52 Public Service Commission, Forty-Ninth Annual Report of the Public Service Commission, paragraph 104.

53 Ibid., paragraph 107.

54 Public Service Commission, Forty-Second Annual Report of the Public Service Commission, paragraph 75 .

55 Public Service Commission, Forty-Fourth Annual Report of the Public Service Commission, paragraph 89.

56 NASA, CEN 68 E1/1/1, 13 November 1951.

57 Public Service Commission, Thirty-Eighth Annual Report of the Public Service Commission, paragraph 204.

58 Public Service Commission, Forty-Third Annual Report of the Public Service Commission, paragraph 17.

59 Ibid.

60 Public Service Commission, Forty-Seventh of the Public Service Commission, paragraph 26.

61 Ibid.

62 Public Service Commission, Forty-Eighth Annual Report of the Public Service Commission (Pretoria: Government Printer, 1959), paragraph 70.

63 Public Service Commission, Fiftieth Annual Report of the Public Service Commission (Pretoria: Government Printer, 1961), paragraph 31.

64 Ibid., paragraph 102.

65 Jackson, Madness and Marginality.

66 Davies, Capital, State and White Labour, 341.

67 Ibid., 340-348.

68 Hansard, volume 70, 71, 72 and 73, 1951, col. 5353.

69 ARCA, PV 94: E.G. Jansen collection, 1/47/26/1, Verslag van die Komitee van Ondersoek na Beskutte Arbeid, Sekretaris van Volkswelsyn.

70 See for instance NASA, VWN 119SW 486 vol. 2, Sekretaris van Volkwelsyn - Die Superintendent, Werkkorps vir Blankes, 13 Maart 1951. See also NASA, TES 4915 F28/428 vol. 1, Direkteur van Gevangenisse - Die Sekretaris van die Tesourie, 22 Julie 1953.

71 NASA,VWN 1850. SWA 274, Conference of work colony superintendents, 1957. Work colonies were semi-penal institutions designed to reform and rehabilitate white men who were not-quite-criminal yet deemed miscreant by state-appointed social workers. See Roos, 'Work Colonies for White Men'. 
72 Public Service Commission, Forty-Fifth Annual Report of the Public Service Commission, paragraph 28.

73 Public Service Commission, Forty-Sixth Annual Report of the Public Service Commission, paragraph 81.

74 Public Service Commission, Forty-Seventh Annual Report of the Public Service Commission, paragraph 52.

75 The idea of 'the steel frame' was made famous by former British Prime Minister David Lloyd George who in 1935 described the Indian Civil Service as 'the steel frame on which the whole structure of our government and administration in India rests'.

76 NASA, ARB, 907 1000/21/1/1/10 vol. 6, 25 January 1957-27 May 1957.

77 Posel, The Making of Apartheid, 3.

78 See for instance Arendt, Eichmann in Jerusalem, 112. 